\title{
PENERAPAN PROFILE MATCHING UNTUK PENCARIAN SISWA SMP PENERIMA BEASISWA MISKIN DAN BERPRESTASI
}

\author{
Muhammad Taufik Irawan'), Danny Kriestanto ${ }^{2)}$ \\ Teknik Informatika, STMIK AKAKOM \\ e-mail: muhammadtaufikirawan@gmail.com ${ }^{1)}$, danny@akakom.ac.id ${ }^{2)}$
}

\begin{abstract}
ABSTRAK
Sistem Pendukung Keputusan pada dasarnya adalah sistem komputer yang bertujuan untuk membantu para pengambil keputusan untuk mengambil keputusan yang sesuai, yang dapat memperhitungkan segala kriteria yang mendukung pengambilan keputusan guna membantu, mempercepat, dan mempermudah proses pengambilan keputusan.

Salah satu metode yang digunakan untuk menentukan calon penerima beasiswa adalah profile matching karena mampu menyeleksi alternative terbaik dari sejumlah alternatif, dalam hal ini alternatif yang dimaksudkan yaitu yang berhak menerima beasiswa berdasarkan kriteria-kriteria yang ditentukan. Penelitian dilakukan dengan menentukan aspek dan sub aspek berserta mencari nilai bobot untuk setiap sub aspek, mencari GAP antara profil dengan keadaan data dari para siswa.Dengan menggunakan metode ini ditentukan presentasi kedua unsur aspek dan dijumlahkan kemudian dilakukan proses perankingan yang akan menentukan alternatif yang optimal, yaitu siswa dengan nilai tertinggi. Ada dua bentuk penerima beasiswa yang digunakan pada penelitian ini, yaitu berdasarkan ekonomi keluarga dan berdasarkan prestasi siswa.

Hasil akhir dari penelitian ini berupa sebuah sistem pendukung keputusan menentukan calon penerima beasiswa yang mampu memberikan solusi berupa hasil rangking dari seleksi Metode Profile Matching berdasarkan kriteria yang telah di tentukan
\end{abstract}

Kata Kunci: Beasiswa, Profile Matching, Sistem Pendukung Keputusan.

\section{ABSTRACT}

Decision Support System is basically a computer system which aims to help decision-makers to take the appropriate decisions, which can take into account all the criteria that support decision making to assist, accelerate and simplify the decision making process.

One of the best methods used to determine scholarship recipients is profile matching. The study was conducted by determining aspects and sub-aspects along with looking for weight values for each sub-aspect, looking GAP between profiles with state of the data of the students. This method represent and summarized both aspects before conducting ranking process that will determine the optimal alternative, that is the students with the highest score. There are two different scholarship introduced in this research: scholarship for poor students and for student with high achievement.

The final results of this study in the form of a decision support system determine scholarship recipients who are able to provide solutions in the form of ranking results Profile Matching Method of selection based on the criteria that has been set.

Keywords: Scholarships, Profile Matching, Decision Support System.

\section{PENDAHULUAN}

$\mathrm{T}$ eknologi Informasi saat ini memiliki peranan yang sangat penting disegala bidang dan aspek kehidupan, baik dalam dunia bisnis, politik hingga perekonomian. Hal ini disebabkan karena pemenuhan kebutuhan masyarakat akan informasi dapat terpenuhi dengan adanya peran serta teknologi informasi. Dalam penerapannya teknologi informasi tidak hanya ditunjukan untuk dunia bisnis, politik hingga perekonomian.

Pendidikan juga bisa dijadikan sebagai penerapan teknologi informasi, salah satunya adalah informasi yang dapat mempermudah dan membantu sekolah dalam menentukan calon penerima beasiswa. Sama halnya dengan SMP Negeri 1 Toili yang telah memiliki program pemberian beasiswa, terkait dengan pengelolaan beasiswa yang masih menggunakan Microsoft Excel tentunya akan mengalami kesulitan, karena banyaknya siswa yang berhak mendapatkan beasiswa dan banyaknya kriteria yang digunakan untuk menentukan keputusan penerima beasiswa yang sesuai dengan yang diharapkan. Ada dua kategori penerima beasiswa di SMP Negeri 1 Toili, yakni: beasiswa miskin dan beasiswa berprestasi.

Dengan menggunakan profile matching diharapkan mampu menyeleksi siswa yang berhak menerima beasiswa berdasarkan kriteria-kriteria yang ditentukan. Penelitian dilakukan dengan menentukan aspek dan sub aspek berserta mencari nilai bobot untuk setiap sub aspek, mencari gap (selisih) antara profil dengan keadaan data dari siswa dengan menggunakan metode ini ditentukan presentasi kedua unsur aspek dan dijumlahkan kemudian dilakukan proses perankingan yang akan menentukan alternatif yang optimal, yaitu siswa dengan nilai tertinggi.

Penelitian yang pernah dilakukan oleh [1] menggunakan AHP, membahas mengenai penentuan calon penerima beasiswa di SMP N 1 Pati dengan menggunakan kriteria penghasilan orang tua, rata-rata nilai rapor, tingkat kejuaraan, dan kegiatan ekstra. Dan penelitian menggunakan metode profile matching yang dibuat oleh [2] membahas tentang penerimaan pegawai koperasi. 
Sistem pendukung keputusan adalah sistem informasi interaktif yang menyediakan informasi, pemodelan dan pemanipulasian data. Sistem itu digunakan untuk membantu pengambilan keputusan dalam situasi yang semiterstruktur dan situasi yang tidak terstruktur, dimana tak seorang pun tahu secara pasti bagaimana keputusan seharusnya dibuat [3].Menurut [3] metode profile matching atau pencocokan profil adalah metode yang sering digunakan sebagai mekanisme dalam pengambilan keputusan dengan mengasumsikan bahwa terdapat tingkat variabel prediktor yang ideal yang harus dipenuhi oleh subyek yang diteliti, bukan tingkat minimal yang harus dipenuhi atau dilewati.

\section{Metode}

\section{A. Metode Penelitian}

\section{Pengumpulan Data}

Data para siswa penerima beasiswa pada tahun-tahun sebelumnya dikumpulkan secara langsung dari lokasi penelitian yakni SMP Negeri 1 Toili. Data yang ada akan dijadikan sebagai sumber pengetahuan bagi sistem pendukung keputusan ini. Pihak sekolah juga menentukan Core factor, Secondary Factor, dan nilai dari aspekaspek yang digunakan dalam penelitian ini.

\section{Analisis Kasus}

Data yang telah dikumpulkan dianalisis sebelum diimplementasikan ke dalam sistem pendukung keputusan. Metode profile matching digunakan karena ada kesesuaian antara metode ini dengan metode seleksi penerima beasiswa yang dilakukan di sekolah.

\section{Perancangan Aplikasi}

Rancang bangun dari aplikasi ini akan dibuat berbasis web. Oleh karena itu, perancangan sistem yang dibuat akan menggunakan diagram konteks dan juga diagram alir data.

Pengujian Aplikasi

Pengujian dilakukan setelah aplikasi berhasil dibangun, dengan cara membandingkan hasil keputusan dari sekolah dan hasil perhitungan berdasarkan aplikasi.

\section{B. Kebutuhan Input}

Penelitian membutuhkan masukan (input) berupa: data siswa, data kriteria, data aspek, data nilai akademik, data nilai non akademik

\section{Kebutuhan Output}

Hasil yang akan diperoleh (output) berupa: laporan siswa yang menerima beasiswa, laporan data presentase siswa, laporan data siswa

\section{Diagram Konteks dan Diagram Alir Data Level Satu}

Model fungsional menggambarkan bagaimana masukan diproses oleh sistem menjadi keluaran yang diharapkan oleh pengguna. Model fungsional memuat beberapa aliran data atau data flow diagram (DFD) yang memperlihatkan aliran data dari luar sistem yang kemudian diproses oleh sistem dan akhirnya menghasilkan keluaran yang berguna [4]. Diagram konteks yang diterapkan pada aplikasi ini dapat dilihat pada Gambar 1. Sistem berinteraksi dengan admin dan pimpinan. Sistem ini menerima input berupa data calon siswa calon penerima beasiswa, kriteria, nilai akademik, nilai non akademik dan data aspek. Setelah semua data telah diinput, maka pimpinan memberikan nilai presentasi aspek dan nilai core factor dan secondary factor untuk menentukan calon penerima beasiswa. Sedangkan output yang dihasilkan berupa laporan untuk pimpinan. Lebih jelasnya mengenai sistem ini dapat dilihat pada DAD level satu pada Gambar 2.

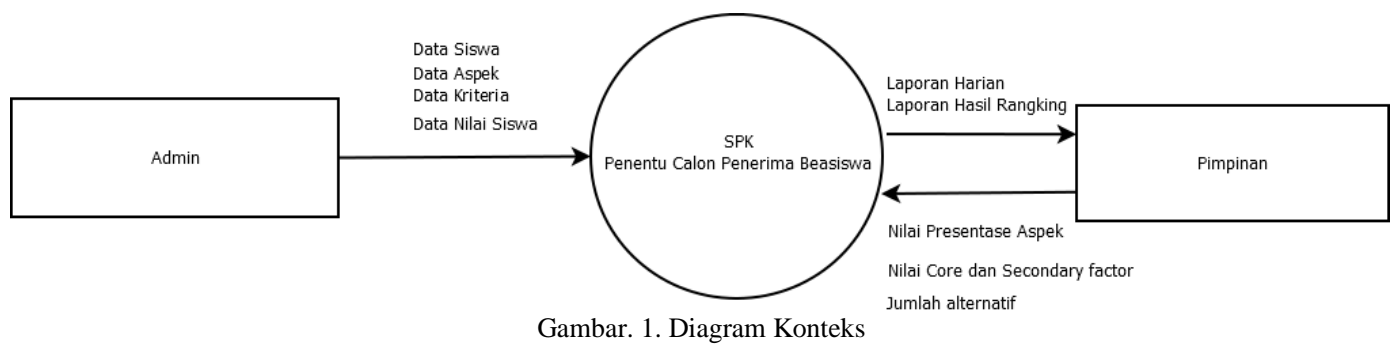




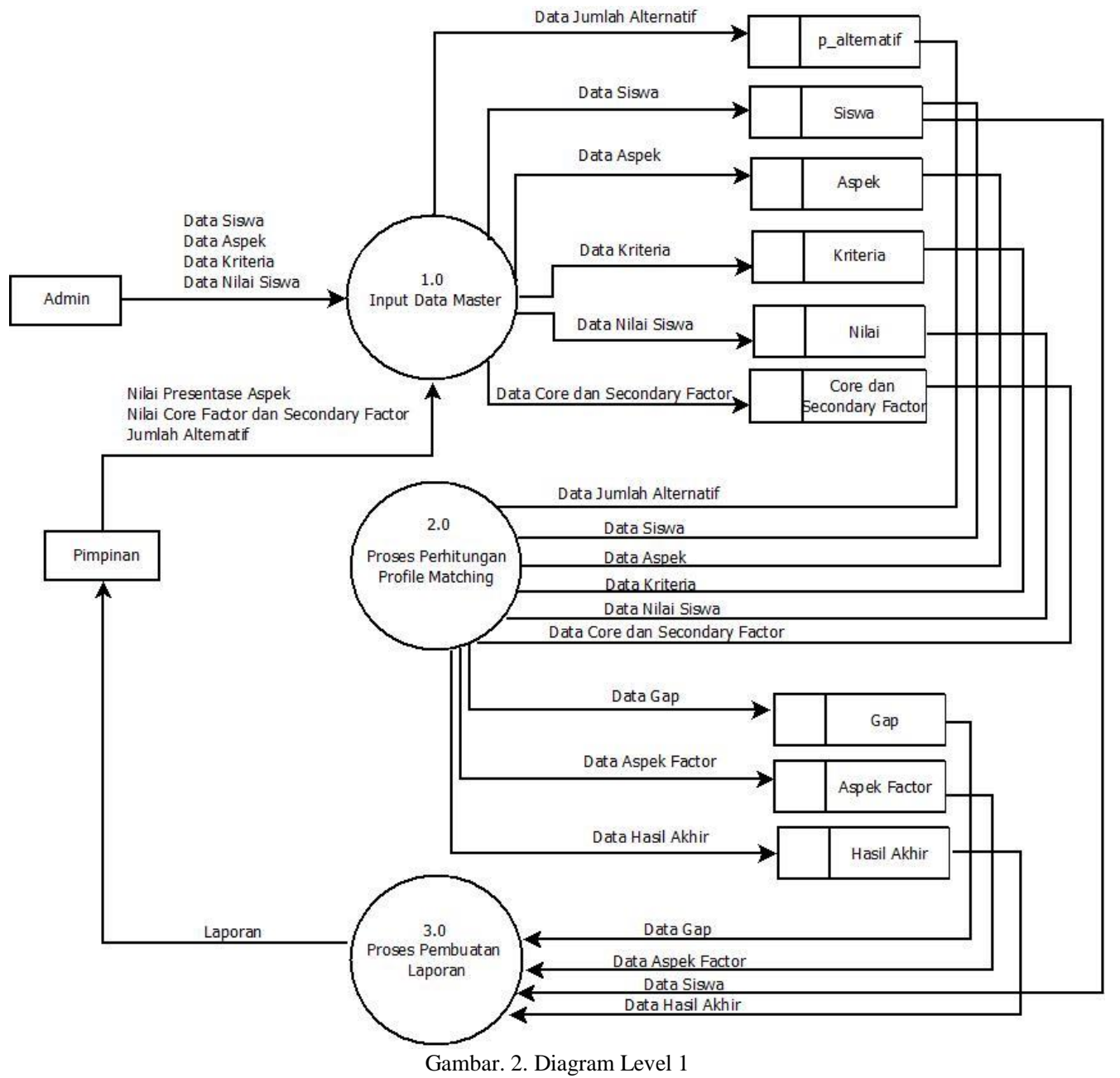

\section{E. Skema Basis Data}

Dalam memproses semua data siswa diperlukan adanya sebuah basis data untuk menampung data-data tersebut. Adapun perancangan skema basis data dari penelitian ini dapat dilihat pada Gambar 3.

1) Profil Ideal/Nilai Standar

Profil Ideal / Nilai Standar yang digunakan dan telah ditentukan oleh pihak sekolah adalah seperti yang tampak pada Tabel I dan Tabel II.

2) Nilai Core Factor dan Secondary Factor

Nilai core factor dan secondary factor yang telah ditentukan oleh pihak sekolah adalah: core factor sebesar $60 \%$ dan nilai secondary factor sebesar 40\% dengan pembagian seperti yang tampak pada Tabel III dan Tabel IV.

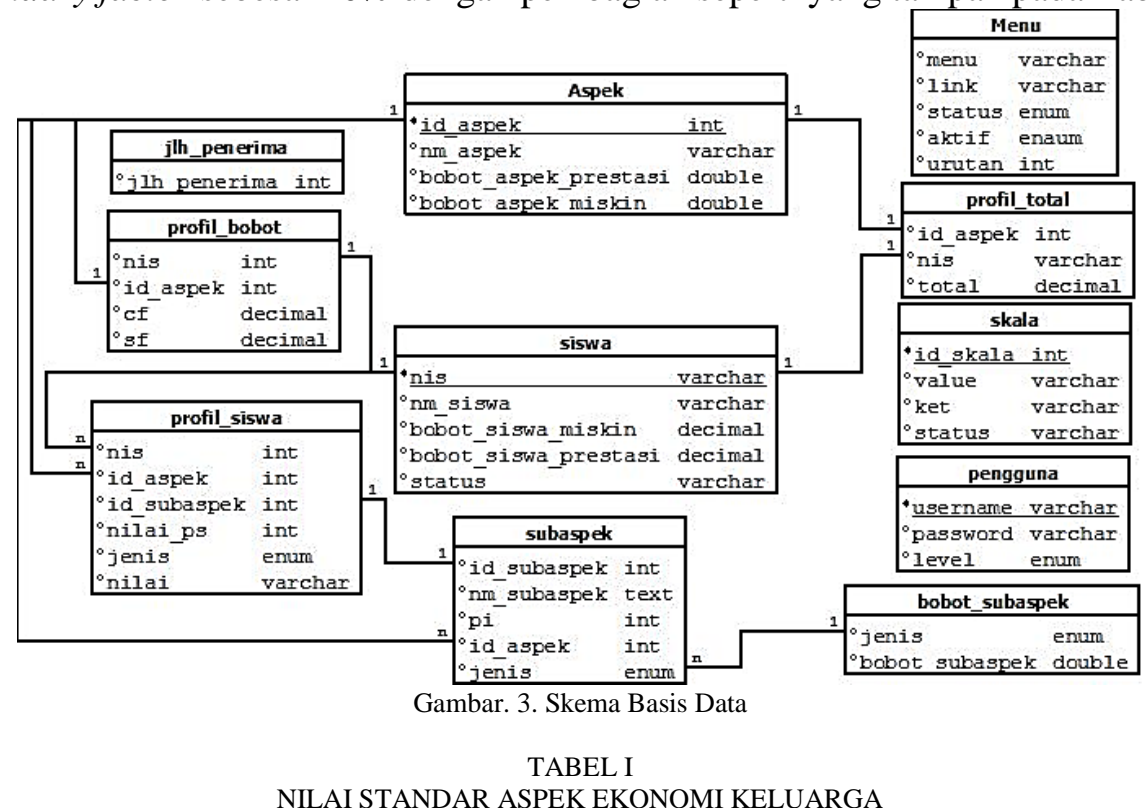




\begin{tabular}{cc}
\hline \hline Status Siswa & Nilai Standar \\
\hline Status Anak & 8 \\
Pekerjaan Ayah & 8 \\
Pekerjaan Ibu & 8 \\
Penghasilan Orang Tua & 9 \\
Tanggungan Orang Tua & 9 \\
\hline \multicolumn{1}{c}{ TABEL II } \\
NILAI STANDAR ASPEK AKADEMIK PRESTASI \\
\hline \hline Mata Pelajaran & Nilai Standar \\
\hline Agama \& Budi Pekerti & 9 \\
PKn & 9 \\
Bahasa Inggris & 8 \\
Matematika & 8 \\
IPA & 8 \\
IPS & 8 \\
Seni Budaya & 8 \\
Prakarya & 8 \\
Penjas & 8 \\
Bahasa Indonesia & 8 \\
Prestasi Non Akademik & 7 \\
Prestasi Akademik & 8 \\
\hline \hline
\end{tabular}

TABEL III

PENENTUAN CORE FACTOR \& SECONDARY FACTOR ASPEK EKONOMI KELUARGA

\begin{tabular}{cc}
\hline \hline Status Siswa & $\begin{array}{c}\text { Penentuan Core Factor \& } \\
\text { Secondary Factor }\end{array}$ \\
\hline Status Anak & Core Factor \\
Pekerjaan Ayah & Secondary Factor \\
Pekerjaan Ibu & Secondary Factor \\
Penghasilan Orang Tua & Core Factor \\
Tanggungan Orang Tua & Core Factor \\
\hline \hline
\end{tabular}

TABEL IV

PENENTUAN CORE FACTOR \& SECONDARY FACTOR ASPEK AKADEMIK PRESTASI

\begin{tabular}{cc}
\hline Mata Pelajaran & $\begin{array}{c}\text { Penentuan Core Factor \& } \\
\text { Secondary Factor }\end{array}$ \\
\hline Agama \& Budi Pekerti & Secondary Factor \\
PKn & Secondary Factor \\
Bahasa Inggris & Core Factor \\
Matematika & Core Factor \\
IPA & Core Factor \\
IPS & Core Factor \\
Seni Budaya & Secondary Factor \\
Prakarya & Secondary Factor \\
Penjas & Secondary Factor \\
Bahasa Indonesia & Secondary Factor \\
Prestasi Non Akademik & Secondary Factor \\
Prestasi Akademik & Core Factor \\
\hline \hline
\end{tabular}

3) Pembobotan Aspek Beasiswa

Dari hasil wawancara dengah pihak sekolah Smp Negeri 1 Toili, ditentukan hasil pembobotan untuk dapat memisahkan hasil beasiswa ekonomi keluarga (BSM) dan Beasiswa Akademik Prestasi pada aplikasi.

a) Pembobotan Beasiswa Aspek Ekonomi Keluarga

1. Aspek Ekonomi Keluarga $70 \%$

2. Aspek Akademik Prestasi 30\%

b) Pembobotan Beasiswa Aspek Akademik Prestasi

1. Aspek Akademik Keluarga 40\%

2. Aspek Ekonomi Prestasi 60\%

\section{A. Analisis Pengujian Program}

III. HASIL

Pengujian sistem dalam penelitian ini menggunakan perhitungan manual sebagai acuan perbandingan hasil manual dengan aplikasi yang dibuat. Pengujian ini dilakukan untuk melihat kecocokan dari hasil yang diperoleh antara aplikasi dengan manual.

\section{B. Hasil Perhitungan Manual}

Pada pengujian ini digunakan data siswa calon penerima beasiswa sesuai dengan kriteria yang telah ditetapkan, Berikut adalah perhitungan manual dengan data seperti yang tampak pada Tabel V. 
TABEL V

TABEL ASPEK PRESTASI AKADEMIK

\begin{tabular}{|c|c|c|c|c|c|c|c|c|c|c|c|c|c|}
\hline NIS & Nama & Agama & PKn & $\begin{array}{c}\text { Bhs } \\
\text { Inggris }\end{array}$ & Mtk & IPA & IPS & $\begin{array}{c}\text { Seni } \\
\text { Budaya }\end{array}$ & $\begin{array}{l}\text { Prak } \\
\text { arya }\end{array}$ & Penjas & $\begin{array}{c}\text { Bhs } \\
\text { Indo }\end{array}$ & $\begin{array}{c}\text { Pres. Non } \\
\text { Akad } \\
\end{array}$ & $\begin{array}{l}\text { Pres. } \\
\text { Akad }\end{array}$ \\
\hline 1111 & Ahmad & 7 & 8 & 7 & 8 & 7 & 7 & 9 & 8 & 7 & 8 & 8 & 8 \\
\hline 1112 & Heri & 8 & 8 & 7 & 8 & 9 & 9 & 8 & 7 & 9 & 8 & 8 & 9 \\
\hline $\begin{array}{l}\text { Profil } \\
\text { ideal }\end{array}$ & & 9 & 9 & 8 & 8 & 8 & 8 & 8 & 8 & 8 & 8 & 7 & 8 \\
\hline 1111 & Ahmad & -2 & -1 & -1 & 0 & -1 & -1 & 1 & 0 & -1 & 0 & 1 & 0 \\
\hline 1112 & Heri & -1 & -1 & -1 & 0 & 1 & 1 & 0 & -1 & 1 & 0 & 1 & 1 \\
\hline
\end{tabular}

TABEL VI

CONTOH ASPEK EKONOMI KELUARGA

\begin{tabular}{ccccccc}
\hline \hline NIS & Nama & $\begin{array}{c}\text { Status } \\
\text { Anak }\end{array}$ & $\begin{array}{c}\text { Pekerjaan } \\
\text { Ayah }\end{array}$ & $\begin{array}{c}\text { Pekerjaan } \\
\text { Ibu }\end{array}$ & $\begin{array}{c}\text { Penghasilan } \\
\text { Orang tua }\end{array}$ & $\begin{array}{c}\text { Tanggungan } \\
\text { Orang tua }\end{array}$ \\
\hline $\mathbf{1 1 1 1}$ & Ahmad & 7 & 8 & 7 & 8 & 9 \\
$\mathbf{1 1 1 2}$ & Heri & 7 & 8 & 8 & 9 & 8 \\
Profil & & 8 & 8 & 8 & 9 & 9 \\
Ideal & & -1 & 0 & -1 & -1 & 0 \\
$\mathbf{1 1 1 1}$ & Ahmad & -1 & 0 & 0 & 0 & -1 \\
$\mathbf{1 1 1 2}$ & Heri & &
\end{tabular}

TABEL VII

CONTOH PERHITUNGAN NILAI TOTAL BEASISWA AKADEMIK

\begin{tabular}{ccccc}
\hline \hline NIS & Nama & Core factor & Secondary factor & Nilai Total \\
\hline $\mathbf{1 1 1 1}$ & Ahmad & 4.4 & 4.2 & 4.32 \\
$\mathbf{1 1 1 2}$ & Heri & 4.5 & 4.4 & 4.46 \\
\hline \hline
\end{tabular}

TABEL VIII

PERHITUNGAN NILAI TOTAL BEASISWAEKONOMI KELUARGA

\begin{tabular}{ccccc}
\hline \hline NIS & Nama & Core factor & Secondary Factor & Nilai Total \\
\hline $\mathbf{1 1 1 1}$ & Ahmad & 4.3 & 4.5 & 4.38 \\
$\mathbf{1 1 1 2}$ & Heri & 4.3 & 5 & 4.58 \\
\hline \hline
\end{tabular}

Pada Tabel V dan Tabel VI dapat dilihat bahwa profil mahasiswa berprestasi untuk setiap kriteria yang digunakan adalah sebagai berikut: Agama $=9, \mathrm{PKn}=9$, Bhs Inggris $=8$, Matematika $=8$, IPA $=8$, IPS $=8$, Seni budaya $=8$, Prakarya $=8$, Penjas $=8$, Bahasa Indonesia $=8$, Prestasi Non-Akademik $=7$, dan Prestasi Akademik $=8$. Selanjutnya pada Tabel IV dan V hasil perhitungan gap untuk setiap alternatif, dengan cara mengurangkan nilai profil siswa dengan nilai profil siswa calon penerima beaiswa. Setelah mendapat data-data setiap aspek maka selanjutnya menghitung nilai total berdasar kan hasil nilai bobot CF dan SF dari setiap aspek dengan menggunakan bobot $\mathrm{CF}=60 \%$ dan $\mathrm{SF}=40 \%$.

Pada Tabel VII dan Tabel VIII adalah tabel data dari perhitungan bobot yang sudah ditentukan datanya dari setiap aspek antara lain aspek akademik dan aspek ekonomi keluarga. Setelah mendapat beberapa nilai yang di dapat dari masing-masing siswa penerima beasiswa yang menghasilkan nilai total berarti selanjutnya dilakukan perangkingan untuk menghitung dan mebandingan untuk menentetukan siapa penerima beasiswa dengan cara sebagai berikut:

Pada Tabel IX adalah data akhir yang di peroleh dari pembobotan setiap aspek yaitu Nilai Ekonomi keluarga 30\% dan Akademik Prestasi 70\% yang kemudian didapatlah hasil yang diperlukan untuk perankingan jika dilihat dari data perolehan hasil akhir maka bisa ditetapkan bahwa calon penerima beasiswa adalah Ahmad dan Heri karena jumlah penerima dapat diatur batasannya untuk dua orang penerima dari menu Jumlah Penerima pada aplikasi.

Pada Tabel $\mathrm{X}$ adalah data akhir yang diperoleh dari pembobotan setiap aspek yaitu Nilai Ekonomi keluarga 60\% dan Akademik Prestasi 40\% yang kemudian didapatkah hasil yang diperlukan untuk perankingan jika dilihat dari data perolehan hasil akhir maka bisa ditetapkan bahwa calon penerima beasiswa adalah Ahmad dan Heri karena jumlah penerima sudah ditetapkan kedalam sistem hanya dua orang penerima.Fitur ini disediakan di dalam aplikasi dan dapat diganti seperti yang tampak pada Gambar 4. Pada saat pemilihan beasiswa untuk contoh kasus Ahmad dan Heri jumlah penerimaditentukan untuk 2 orang, baik untuk beasiswa berprestasi dan beasiswa miskin.

\section{Hasil Perhitungan Aplikasi}

Adapun hasil uji coba dengan menggunakan data yang sama dengan menggunakan aplikasi yang dibangun dapat dilihat pada Gambar 5. 
TABEL IX

HASIL RANGKING BEASISWA ASPEK EKONOMI KELUARGA (BSM)

\begin{tabular}{ccccc}
\hline \hline NIS & Nama & $\begin{array}{c}\text { Nilai Aspek } \\
\text { Ekonomi Keluarga }\end{array}$ & $\begin{array}{c}\text { Nilai Aspek Prestasi } \\
\text { Akademik }\end{array}$ & Bobot \\
\hline $\mathbf{1 1 1 1}$ & Ahmad & 4.38 & 4.32 & 4.356 \\
$\mathbf{1 1 1 2}$ & Heri & 4.58 & 4.46 & 4.532 \\
\hline \hline
\end{tabular}

TABEL X

HASIL RANGKING BEASISWA ASPEK AKADEMIK PRESTASI

\begin{tabular}{ccccc}
\hline \hline NIS & Nama & $\begin{array}{c}\text { Nilai Aspek } \\
\text { Ekonomi } \\
\text { Keluarga }\end{array}$ & $\begin{array}{c}\text { Nilai Aspek } \\
\text { Prestasi } \\
\text { Akademik }\end{array}$ & Bobot \\
\hline $\mathbf{1 1 1 1}$ & Ahmad & 4.38 & 4.32 & 4.338 \\
$\mathbf{1 1 1 2}$ & Heri & 4.58 & 4.46 & 4.496 \\
\hline \hline
\end{tabular}

Seleksi Jumlah Penerima Beasiswa Smp Negeri 1 Toili

\begin{tabular}{|l|l|}
\hline JUMLAH PENERTMA BEASISWA PRESTASI & AKSI \\
\hline 23 Orang & EdIt \\
\hline JUMLAH PENERTMA BEASISWA MISKIN & AKSI \\
\hline 20 orang & Edit \\
\hline
\end{tabular}

Gambar. 4. Pemilihan Jumlah Penerima Beasiswa

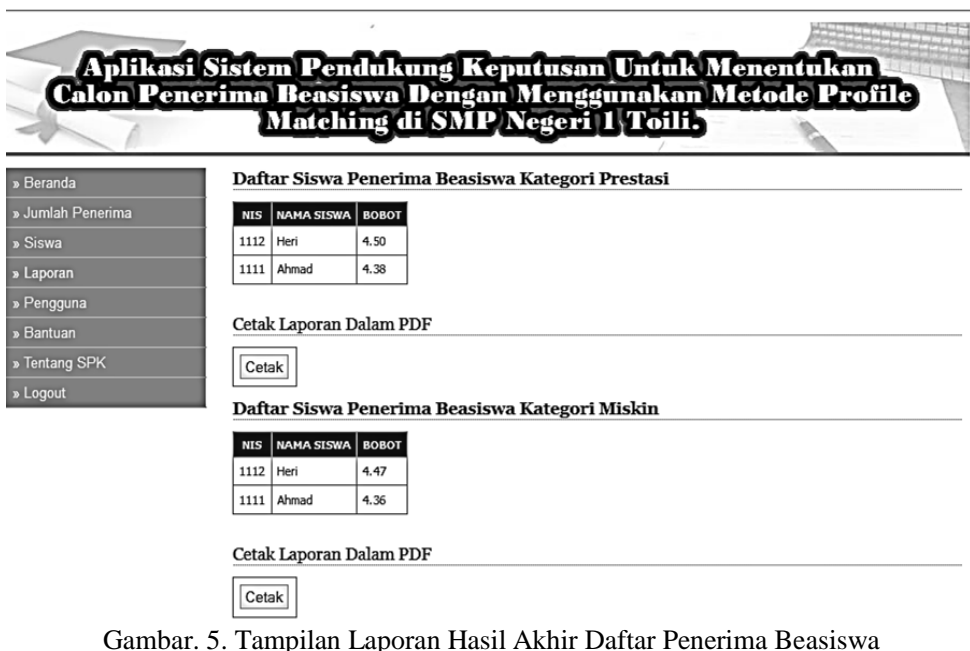

Hasil akhir dari pengujian yang dilakukan pada sistem yang telah dibangun ternyata juga menghasilkan urutan rangking yang sama serta dengan nilai ranking yang sama pula yaitu penerima beasiswa adalah Ahmad dan Heri. Adapun jumlah siswa calon penerima beasiswa yang ditampilkan dapat diatur dalam aplikasi ini melalui menu Jumlah Penerima.

\section{SIMPULAN DAN SARAN}

Adapun kesimpulan yang dapat diambil dalam penelitian ini adalah:

1) Sistem Pendukung Keputusan ini dapat digunakan untuk melakukan seleksi siswa penerima beasiswa.

2) Sistem Pendukung Keputusan ini dapat digunakan untuk menentukan dua macam tipe beasiswa, yakni beasiswa miskin dan beasiswa berprestasi.

3) Proses ranking dilakukan dengan menentukan persentase bobot masing-masing tipe beasiswa.

4) Tidak ada perbedaan yang signifikan antara hasil perhitungan secara manual maupun dengan menggunakan aplikasi dalam penelitian ini.

5) Adapun saran yang dapat diberikan untuk pengembangan sistem adalah metode ini dikomparasikan dengan metode lain seperti metode Analytical Hierarchy Processatau Simple Additive Weighting.

\section{REFERENSI}

[1] Tri Rukmana Sari, "Sistem pendukung keputusan menggunakan metode AHP untuk menentukan calon penerima beasiswa di SMP NEGERI 1 PATI", STMIK AKAKOM, Yogyakarta, 2014.

[2] Alfian Eko Saputro, "Sistem pendukung keputusan penerimaan pegawai Koperasi Serba Usaha Pijartirta Manunggal di Giritirto dengan metode Profile Matching", STMIK AKAKOM, Yogyakarta, 2014.

[3] Kusrini, Konsep dan Aplikasi Sistem Pendukung Keputusan. Andi, 2007.

[4] Jogiyanto, Analisis dan Desain Sistem Informasi: Pendekatan Terstruktur Teori dan Praktik Aplikasi Bisnis, Andi, Yogyakarta, 2005. 